\title{
A ANÁLISE TEXTUAL DISCURSIVA NA PESQUISA QUALITATIVA NO ENSINO DE FILOSOFIA: PENEIRADAS INTEMPESTIVAS NO PROF-FILO
}

\author{
DISCURSIVE TEXTUAL ANALYSIS IN QUALITATIVE RESEARCH IN \\ TEACHING PHILOSOPHY: INTEMPESTIVE SCREENING IN PROF-FILO
}

\author{
Sônia Maria Lira Ferreira ${ }^{1}$ \\ Rosemary Marinho da Silva ${ }^{2}$ \\ Gabriela da Nóbrega Carreiro ${ }^{3}$
}

\begin{abstract}
Resumo: Diante do significativo lugar do PROF-FILO na produção acadêmica para o ensino de filosofia enquanto área de pesquisa filosófica, este artigo objetiva desvelar alguns dos elementos metodológicos de pesquisas realizadas nesse mestrado profissional, elencando contribuições para o ensino de filosofia. Para tal, definimos como pergunta-problema: "o que é isso que se mostra de pesquisas qualitativas nas dissertações do PROF-FILO?". Estabelecemos sete dissertações, produzidas pela primeira turma do PROF-FILO (2017-2019), como corpus investigativo. O guia de análise, que metaforicamente denominamos de nossa "peneira", foi a Análise Textual Discursiva (ATD). A partir dessas escolhas, três abordagens metodológicas apresentaram-se com significativa recorrência: pesquisa fenomenológica, pesquisa-ação e pesquisa intervenção. Apontamos, como elemento expressivo, a abertura para o interrogar e o compreender o mundo das vivências dos sujeitos envolvidos com o processo de ensinoaprendizagem da filosofia.
\end{abstract}

Palavras-chave: Pesquisa qualitativa; Análise Textual Discursiva; Ensino de Filosofia.

\begin{abstract}
Given the significant role of PROF-FILO in academic production for the teaching of philosophy as an area of philosophical research, this article aims to reveal some of the methodological elements surrounding the research carried out in this professional master's, listing contributions to the teaching of philosophy. Thus, the problem question is defined as: "What is it that shows up in qualitative research in the PROF-FILO theses?". We established seven dissertations, produced by the first class of PROF-FILO (2017-2019), as an investigative corpus. The analysis guide, which is metaphorically called "sieve", is the Discursive Textual Analysis (DTA). Choices led to three methodological presented with significant recurrence: phenomenological research, action research and intervention research. A significant element is the openness to interrogate and understand the world of experiences of subjects involved in Philosophy teaching and learning.
\end{abstract}

Keywords: Qualitative research; Discursive Textual Analysis; Philosophy Teaching.

\section{Introdução}

O ensino de filosofia no Brasil ocupa um lugar formativo na educação superior, nas licenciaturas e na educação básica. Na educação básica, após longo percurso de

\footnotetext{
${ }^{1}$ Doutoranda em Educação na Universidade Federal de Alagoas (PPGE-UFAL); professora de filosofia no Campus de Sumé/UFCG; Campina Grande - PB, Brasil. E-mail: sonialira.filosofia@gmail.com

${ }^{2}$ Doutora em Educação pela Universidade Federal da Paraíba (PPGE-UFPB); professora de filosofia no Campus IV/UFPB; Rio Tinto - PB, Brasil. E-mail: rosemarymarinhodasilva@ gmail.com

${ }^{3}$ Doutoranda em Educação na Universidade Federal da Paraíba (PPGE-UFPB), João Pessoa-PB, Brasil.

E-mail: gncarreiro@gmail.com
} 
negação, luta, organização e mobilizações, esse lugar foi consolidado, especialmente no Ensino Médio, a partir da Lei 11.684/2008. Professoras/es de Filosofia vêm, gradativamente, reconhecendo-se como pesquisadoras/es de sua prática pedagógica, mesmo havendo poucas licenciaturas que encarem o ensino da filosofia como uma problemática filosófica. Por isso, o Programa de Mestrado Profissional em Filosofia PROF-FILO, organizado em rede nacional, com sede na Universidade Federal do Paraná (UFPR), e 15 núcleos distribuídos em universidades de todas as regiões do Brasil, tornou-se um marco histórico/político para o ensino de filosofia brasileiro. Desde a sua implementação, em 2015, o programa tem-se configurado como significativo espaço formativo para essas/es professoras/es-pesquisadoras/es.

Diante do relevante papel do PROF-FILO para o fortalecimento do ensino e da pesquisa, como também para o aprimoramento da formação continuada de professoras/es de Filosofia da educação básica, este artigo objetiva desvelar alguns elementos metodológicos das dissertações realizadas nesse mestrado, manifestando contribuições para o ensino de filosofia como área de pesquisa no campo filosófico. Para tal, definimos como pergunta-problema inicial: "o que é isso que se mostra de pesquisa qualitativa nas dissertações no PROF-FILO?”. O guia de análise, que metaforicamente denominamos de nossa "peneira", foi a Análise Textual Discursiva (ATD), e o processo de análise das dissertações - configurado como "peneiradas" envolveu dois momentos.

Primeiramente, desenvolveu-se a investigação do que se mostrou de abordagem qualitativa nos resumos das 156 dissertações dispostas no site $e^{4}$ do PROF-FILO. Nessa aproximação, ou peneirada, deparamo-nos com o primeiro fenômeno: 80 dissertações escolheram uma teoria filosófica, ou mesmo o pensamento de um filósofo, apontando-o como base de proposta didática e reflexão geral para o ensino de filosofia, sem evidenciar um campo empírico, nem caminho metodológico de levantamento de dados provindos desse campo. As 76 dissertações restantes, que se autoafirmaram como pesquisas qualitativas, indicaram, de modo recorrente, três abordagens metodológicas qualitativas, que foram as seguintes: Pesquisa Fenomenológica, Pesquisa-ação e Pesquisa-Intervenção (ou intervenção filosófica). Esses três tipos de pesquisa, por conta de suas frequências, foram considerados categorias reorientadoras da pergunta-

\footnotetext{
4 Banco de dissertações do PROF-FILO. Disponível em: http://www.humanas.ufpr.br/portal/prof-
} filo/dissertacoes-defendidas/ 
problema inicial e, consequentemente, da organização de análise das dissertações presentes neste artigo.

Em um segundo momento, a partir desse reordenamento, debruçamo-nos sobre os capítulos metodológicos e dos resultados dessas 76 dissertações, conduzindo-nos pela seguinte pergunta-problema: "o que é isso que se mostra de pesquisa fenomenológica/pesquisa-ação/pesquisa-intervenção, enquanto pesquisas qualitativas, nas 76 dissertações do PROF-FILO?”. Nesta segunda peneirada, sob os critérios da "lógica interna da pesquisa" (GAMBOA, 2012, p. 58), que consiste no alinhamento explícito e de rigor epistemológico e metodológico entre problema de pesquisa, campo de pesquisa, escolha do tipo de pesquisa, definição de procedimentos de coleta de dados, análise dos dados e apresentação de resultados, evidenciou-se o segundo fenômeno: duas dissertações de viés fenomenológico, duas de pesquisa-ação e três de pesquisa-intervenção (ou pesquisa de intervenção filosófica) apresentaram uma lógica interna consistente, que favoreceu o cumprimento do objetivo que nos colocamos. Esse segundo fenômeno, observado nas sete dissertações, configurou-se como o corpus de análise tratado neste artigo.

Esses dois movimentos, ou peneiradas, exigiram-nos um permanente exame de nossa compreensão, provinda de sentidos e teorias implícitas (MORAES; GALIAZZI, 2016), sobre pesquisa qualitativa. Percebemos que a abordagem qualitativa propicia "a obtenção de dados descritivos sobre pessoas, lugares e processos interativos (...) para compreender os fenômenos segundo a perspectiva dos sujeitos, ou seja, dos participantes da situação em estudo" (GODOY, 1995, p.58). Gil (2008) concorda, afirmando que a compreensão de significados do cotidiano pelos sujeitos envolvidos com a pesquisa exige uma combinação de diversas estratégias. Essa combinação acentua-se como enfoques "multi/inter/transdisciplinares e tratamentos multidimensionais" (ANDRÉ; GATTI, 2013, p. 34), que podem ser revisados e revisitados durante o processo de investigação (MCMILLAN; SCHUMACHER, 2005) no campo de atuação de professoras/as-pesquisadoras/es.

Essas características da pesquisa qualitativa cortam e recortam as decisões no modo de coletar e dispor as informações, compreensões e interpretações do corpus analisado neste artigo. Soma-se a fundamental contribuição da ATD a esse processo de exame epistemológico/metodológico, por propiciar um afastamento do corpus empírico a fim de perceber elementos que favorecem uma compreensão mais ampla e profunda do objeto pesquisado. A ATD abrange "uma sequência recursiva de três componentes: 
desconstrução dos textos do corpus, a unitarização; estabelecimento de relações entre os elementos unitários, a categorização; o captar do novo emergente em que a nova compreensão é comunicada e validada" (MORAES, 2003, p. 192) como metatexto.

Para gerar unidades, faz-se preciso fragmentar o texto, reescrever cada unidade e buscar expressões das ideias centrais por meio de nomeação. A categoria é um modo de produção de descrições e interpretações que vão resultar na compreensão do fenômeno estudado. A elaboração do metatexto é um processo de descrição e de interpretação. A descrição é um "esforço de exposição de sentidos e significados em sua aproximação mais direta com os textos analisados" (MORAES, 2003, p. 203). A interpretação é a parte do texto na qual se constroem "novos sentidos e compreensões" (MORAES, 2003, p. 204). Portanto, o modo como construímos o metatexto deu-se como um discurso articulado, por constituir-se no tratamento das unidades de significados enquanto "asserções, que correspondam o mais fidedignamente possível ao discurso do sujeito" (ROJAS et al., 2010, p. 5) das dissertações investigadas, articulando-as com nossas próprias compreensões e com as das/os autoras/es citadas/os neste artigo.

Diante dessas escolhas, estruturamos nosso artigo em três peneiradas, que nos proporcionaram uma composição teórico-metodológica de análise das dissertações. $\mathrm{Na}$ primeira, tratamos de alguns aspectos do PROF-FILO como cenário de aparecimento das pesquisas. Indicamos, na segunda, alguns traços epistemológicos dos três tipos de pesquisa recorrentes nas dissertações. Como terceira peneirada, foi realizada uma análise das sete dissertações (duas dissertações de pesquisa fenomenológica, duas de pesquisa-ação e três de pesquisa-intervenção) que apresentaram alinhamento na lógica interna da pesquisa (GAMBOA, 2012). Por fim, nas considerações finais, a partir das contribuições da ATD, sinalizamos possibilidades investigativas para o ensino de filosofia, mediante outros olhares para seu fortalecimento como área de pesquisa filosófica.

\section{PROF-FILO: um cenário de aparecimento epistêmico/metodológico}

A discussão de criação dos Mestrados Profissionais, na área de ensino, é recorrente desde o ano de 2001. Somente em 2005, a Coordenação de Aperfeiçoamento Profissional de Nível Superior (CAPES), reunida com coordenadoras/es das áreas de conhecimento, promoveu o Seminário "Para além da academia - A pós-graduação contribuindo para a sociedade" (RIBEIRO, 2005), no qual a proposta dessa nova 
modalidade de mestrado foi absorvida e passou a compor as ofertas de pós-graduação das Instituições de Ensino Superior.

A constituição do PROF-FILO emergiu de problemáticas que circundam os limites formativos dos cursos de licenciatura em Filosofia, especialmente advindos da implementação dessa disciplina no currículo escolar da educação básica. Em virtude da obrigatoriedade da disciplina como componente curricular, legitimada na Lei 11.684 de 2008, as problemáticas do ensino, tanto no Ensino Médio quanto no Fundamental, passaram a demandar questões pedagógicas e filosóficas para as/os professoras/es. Conforme aponta Velasco (2019), a constituição do PROF-FILO resultou do engajamento histórico de um amplo movimento em defesa da presença do ensino de filosofia na educação básica, especialmente com a criação do Grupo de Trabalho (GT) "Filosofar e Ensinar Filosofar", vinculado à Associação Nacional de Pós-graduação em Filosofia (ANPOF).

A estrutura curricular desse mestrado é composta de disciplinas que integram duas linhas de pesquisas: a) Filosofia e Ensino; e b) Prática de Ensino de Filosofia. Essas linhas potencializam projetos e produções educativo-filosóficas com/sobre/para o ensino de filosofia. Conforme aponta Velasco (2019, p. 8-91), os projetos de pesquisa e as dissertações "envolvem uma dimensão prática, acolhendo as reflexões sobre as experiências docentes", valorizando os fazeres pedagógicos como lugar de pesquisa filosófica e as/os professoras/es de Filosofia como sujeitos de produção de conhecimento a partir de seu fazer-aprender-ensinar filosofia. Essa estruturação favoreceu o aparecimento da pesquisa qualitativa como uma possibilidade de produção acadêmica que interliga a filosofia e a educação.

\section{Pesquisas e campos epistemológicos das dissertações qualitativas do PROF-FILO}

Com o intuito de valorização de uma pesquisa de cunho qualitativo, que nasce das práticas docentes teorizadas para ampliá-las fortalecê-las, buscamos contornar os campos epistemológicos dos três tipos de pesquisas que se mostraram recorrentes nas 76 dissertações que se autodefiniram como qualitativas. A pesquisa fenomenológica, a pesquisa-ação e a pesquisa-intervenção aparecem como categorias que, de acordo com a ATD, possibilitam uma "construção de estruturas compreensivas" (MORAES; GALIAZZI, 2016, p. 96) do fenômeno investigado neste artigo. 


\subsection{Pesquisa Fenomenológica - a compreensão do sentido do fenômeno que se mostra no ato investigativo}

Com a pretensão de atingir a compreensão do sentido da pesquisa fenomenológica enquanto um tipo de pesquisa qualitativa, foi realizado um diálogo filosófico com as/os seguintes autoras/es: Joel Martins; Magali Roseira Boemer; Clarice Aparecida Ferraz (1990); Edmund Husserl (2012, 2006), Joel Martins; Maria Aparecida Viggiani Bicudo (1989), Angela Ales Bello (2006) e Carlos Diógenes C. Tourinho (2015).

A busca do sentido da pesquisa de viés fenomenológico remete-nos à etimologia da palavra "fenomenologia", que é constituída por duas partes: do termo "fenômeno", que "significa aquilo que se mostra; não somente aquilo que aparece ou parece", e de "logia", que "deriva da palavra logos, que para os gregos tinha muitos significados: palavra, pensamentos" (BELLO, 2006, p. 17-18). Com essa composição, podemos afirmá-la como "reflexão sobre um fenômeno ou sobre aquilo que se mostra" (BELLO, 2006, p. 18). Por isso, o problema de uma pesquisa de viés fenomenológico é compreender "o que é que se mostra e como se mostra" (BELLO, 2006, p. 18). A compreensão do fenômeno investigado deverá ser assumida pelas/os pesquisadoras/es como ponto principal no processo da pesquisa enquanto via de desvelamento e interpretação do sentido do fenômeno.

Edmund Husserl define a fenomenologia como "a doutrina universal das essências, em que se entrega a ciência da essência do conhecimento" (HUSSERL, 2012, p. 20). Para atingir a essência do que se mostra, é necessário partir de um método ou, como salienta Boemer; Ferraz; Martins (1990, p. 143), de uma "trajetória que melhor expressa o caminhar em busca da essência do fenômeno". Dessa forma, assumir a perspectiva fenomenológica como um caminho investigativo significa admitir um percurso que tem como objetivo principal atingir a compreensão do fenômeno sobre o qual se debruça. Isso, certamente, exige das/os pesquisadoras/es uma mudança de atitude - mas em que consiste essa mudança? A que ela se refere? De acordo com Husserl, a mudança está intrinsecamente relacionada ao abandono da atitude natural. Evidencia-se que, na atitude natural, não se tem uma preocupação em questionar o conhecimento, porque, no seu âmago, o conhecimento é considerado como "a coisa mais óbvia de todas" (HUSSERL, 2012, p. 39). 
As/Os pesquisadoras/es que optam pela pesquisa de viés fenomenológico assumem a postura metodológica na qual, como afirma Tourinho (2015), não se nega a existência do mundo natural, pois a finalidade é mostrar a própria compreensão do sentido desse mundo, que se constitui, de forma intencional, no seio da subjetividade transcendental. É pertinente que a escolha da pesquisa fenomenológica seja compreendida como um tipo de pesquisa qualitativa que tem como interesse essencial voltar-se para os eventos que se mostram no cotidiano, com o intuito de atingir a compreensão de suas essências. Como diz Husserl (2006, p. 85),

\begin{abstract}
seguimos nosso princípio geral de que cada evento individual tem sua essência, que é apreensível em pureza eidética e, em sua pureza, tem de fazer parte de um campo de investigação eidética possível. Por conseguinte, os fatos naturais gerais 'eu sou', 'eu penso', 'tenho um mundo diante de mim' e outros semelhantes também têm seus conteúdos eidéticos, e é exclusivamente destes que pretendemos agora nos ocupar.
\end{abstract}

Para compreender esses conteúdos eidéticos, Husserl (2012, 2006) constituiu uma estratégia metodológica a partir de três etapas. Na primeira, faz-se a opção pela vivência da epoché, ou seja, a "suspensão de juízo", o que significa abster-se de elaborar considerações acerca da existência das coisas. O mundo não deixa de ser vivenciado enquanto tese, pois se encontra diante do ser humano, de maneira imediata e sem nenhum impedimento, uma vez que se revela na experiência sensível desse ser humano. A segunda etapa da trajetória investigativa diz respeito ao sujeito que faz uma reflexão. Husserl $(2012,2006)$ afirma que o ponto de partida é perceber quem é o sujeito e por que busca intencionalmente o sentido. Essa etapa é chamada de redução eidética, que pode ser compreendida como um mostrar-se, um desnudar-se do fenômeno além da sua aparência. Ao vivenciar-se a epoché, ou seja, a "suspensão de juízo", dos pré-conceitos, descrevem-se os fenômenos vivenciados na consciência intencional do sujeito investigado. Mediante a descrição, faz-se necessário que as/os pesquisadoras/es se empenhem na terceira etapa, concernente ao momento da interpretação, ou seja, é o passo em que se decifrará o sentido aparente do fenômeno, mostrando os seus sinais da significação.

Para a fenomenologia, todo e qualquer tipo de fenômeno está intrinsecamente relacionado com o mundo humano. Dessa forma, todo fenômeno consiste em uma multiplicidade de significados. Na pesquisa fenomenológica, as/os pesquisadoras/es direcionam-se ao encontro dos depoimentos dos sujeitos da pesquisa ${ }^{5}$, mediante uma

\footnotetext{
${ }^{5}$ No âmbito da pesquisa fenomenológica, utiliza-se o termo "sujeito da pesquisa" compreendendo-o como aquele que, segundo Bicudo (2011), vivencia e cria sentidos no mundo de forma imediata por meio da
} 
pergunta aberta geral, sem limitar sua exposição sobre o tema investigado. Vale apresentar a fala de Martins; Bicudo (1989, p. 77) sobre a investigação de viés fenomenológico:

\begin{abstract}
tematizar e compreender eideticamente significam tomar o fenômeno seriamente diante dos olhos e estudá-lo de maneira sistemática para poder vir a compreender o objeto na sua intenção total, na sua essência, e não apenas na sua representação. Deixa-se de lado, com esse modo de proceder, a experiência empírica (Erfahrung) para assumir a experiência consciente (Erlebnis).
\end{abstract}

Portanto, na explicitação da natureza e dos passos da pesquisa fenomenológica, é relevante enfatizar que o/a pesquisador/a deve preocupar-se com a natureza do fenômeno a ser investigado, pela ausência da compreensão prévia, de modo que inicia sua investigação respeitando as "dúvidas existentes sobre o fenômeno pesquisado e procura mover-se lenta e cuidadosamente de forma que ele possa permitir aos seus sujeitos trazerem à luz o sentido por eles percebidos sobre o mesmo" (MARTINS; BICUDO, 1989, p.92). Essa é a postura ética do processo investigativo no contexto da pesquisa fenomenológica e também o que a caracteriza como uma pesquisa em que as/os pesquisadoras/es e os sujeitos da pesquisa assumem um diálogo intersubjetivo diante do mostrar-se do sentido do fenômeno investigado.

\title{
3.2 Pesquisa-ação - processos participativos e de socialização de saberes e conhecimentos
}

A pesquisa-ação, que surge como categoria das dissertações analisadas, emerge como abordagem metodológica no período após a Segunda Guerra, tendo o psicólogo alemão Kurt Lewin como um de seus primeiros precursores, dedicando-se a aplicá-la no âmbito da psicologia a partir da compreensão desse modo de investigar estruturado em torno do planejamento, da ação, da observação e da reflexão. Além de Lewin, outros estudiosos, como Carr e Kemmis, Laurence Stenhouse e Elliott, dispuseram-se a compreender e difundir a pesquisa-ação como abordagem metodológica. Importante ressaltar que Laurence Stenhouse e Elliott são responsáveis pela vinculação epistemológica e metodológica da pesquisa-ação no campo da educação básica, especialmente em pesquisas sobre a formação de professoras/es (MALLMANN, 2015).

No Brasil, a pesquisa-ação ganha território epistemológico e metodológico a partir da década de 1960. As produções sobre o fazer pesquisa-ação, na constituição dos

intencionalidade da consciência, ou seja, do movimento em que a consciência sempre está direcionada para um objeto; dessa forma, é aquele que experiencia o fenômeno. 
manuais de metodologia, são difundidas com o fervor dos movimentos populares na América Latina. Isso potencializou o fortalecimento de pesquisas de natureza qualitativa, em que o protagonismo popular e a resolução coletiva de problemas sociais, com vistas à transformação, embasaram pesquisadoras/es na produção de pesquisas engajadas, com "articulação da ampla visão da ação e da interação social" (THIOLLENT, 2011, p. 95). A participação, como conceito principal, ocupou e ocupa centralidade na pesquisa-ação e está assentada como um dos requisitos/etapas de desenvolvimento dessa abordagem metodológica. Ela reitera a concepção de uma pesquisa qualitativa de caráter coletivo e cooperativo.

Thiollent (2011) aponta que as áreas de conhecimento que têm se dedicado à utilização da pesquisa-ação como caminho metodológico são: Educação, Comunicação, Serviço Social, Práticas Políticas, Organização e Sistemas, Desenvolvimento Rural e Difusão de Tecnologias, entre outras. Especialmente no campo educacional brasileiro, a pesquisa-ação vem não apenas se fortalecendo e se consolidando continuamente como abordagem metodológica nas pesquisas em educação/ensino, mas também estruturando metodologias de ação no âmbito das práticas pedagógicas e dos projetos de extensão. Inclusive, tem motivado reflexões sobre pressupostos epistêmicos no fomento a políticas públicas educacionais, como as "Diretrizes Curriculares Nacionais para a Formação de Professores da Educação Básica (BRASIL, 2002), ao preconizar que os projetos pedagógicos contemplem o princípio geral da ação-reflexão-ação" (MALLMANN, 2015, p. 78).

Diferentemente da pesquisa fenomenológica, que está estruturada na relação direta com uma corrente filosófica (Fenomenologia), a pesquisa-ação fundamenta-se em um vasto arsenal teórico-filosófico (com, inclusive, distintas concepções gnosiológicas), mas apresenta conceitos filosóficos basilares, como ação, reflexão e transformação. Assim, a pesquisa-ação, como abordagem metodológica que comporta múltiplas ações de pesquisa, pode ser fundamentada nas reflexões da Fenomenologia, da Dialética e da Hermenêutica, dentre outras.

Desse modo, a pesquisa-ação ganha espaço no âmbito das pesquisas que possibilitam interpretações e transformações do cotidiano investigado, do problema posto em questão. Assim, vincular essa forma de conceber a pesquisa no espaço escolar potencializou práticas pedagógicas mais horizontais, aproximando professoras/es de suas/seus estudantes, potencializando os processos de ensino-aprendizagens como temas de pesquisa, de produção de conhecimento, e não somente de reprodução ou 
socialização de saberes já consolidados. Conforme aponta Franco (2012), entende-se que a pesquisa-ação constitui-se como instrumento pedagógico da práxis docente, que colabora no exercício de perceber a prática educacional cotidiana como lugar do fazer pesquisa, encontrando no "processo investigativo coletivo um caminho para transformações em suas práticas e no próprio ambiente profissional” (p. 115).

A concepção gnosiológica que compõe a pesquisa-ação rompe com a dicotomia positivista do sujeito-objeto. A constituição das/os pesquisadoras/es dá-se na/pela relação com aquelas/es que compõem e também produzem a pesquisa, ou seja, o lugar que as/os pesquisadoras/es assumem ao desenvolverem esse caminho metodológico exige a compreensão pedagógica da pesquisa como potencialidade autoformativa coletiva. Nessa relação formativa, são constituídos saberes que se transformam em ações, em superação de situações/problemas que envolvem os sujeitos (pesquisadoras/es e pessoas participantes $)^{6}$ que compõem dialogicamente a pesquisa em questão.

$\mathrm{O}$ engajamento que essa abordagem metodológica requer dos sujeitos da pesquisa, conforme aponta Franco (2012), é uma compreensão coletiva de inserção e envolvimento com os processos da pesquisa, o que se provoca a partir do exercício contínuo da reflexão na ação. É na execução da pesquisa, por meio de diálogos sistemáticos, que se rompe a inércia, possibilitando protagonismos no espaço formativo. Desse modo, mobiliza-se e organiza-se, em tempo, espaço e relações, uma pesquisa que provoca pesquisadoras/es e pessoas participantes a outra forma de vivenciar os processos de investigação. Isso significa que o desenvolvimento completo da pesquisa resulta do engajamento e do interesse dos sujeitos que assumem o pacto de produzir conhecimentos coletivos, a partir do problema elencado por esses mesmos sujeitos.

\subsection{Pesquisa-intervenção - desacomodação de saberes e vivências intersubjetivas e micropolíticas}

Ao configurar-se como uma terceira categoria que se mostra nas 76 dissertações autodefinidas como qualitativas, a pesquisa-intervenção tem suas bases teóricas em profundo diálogo com o paradigma fenomenológico (apresentado no tópico acima) e as filosofias que tratam dos conceitos e teorias em torno da diferença e da complexidade.

\footnotetext{
6 A compreensão de que "sujeitos da pesquisa" são tanto as/os pesquisadoras/es quanto as pessoas pesquisadas é uma característica das pesquisas de caráter participativo - lugar-comum para pesquisa-ação (FRANCO, 2012) e pesquisa intervenção (ROCHA; AGUIAR, 2003). Por isso, a utilização das terminologias "pesquisadoras/es e pessoas participantes" será recorrente nos tópicos que tratam desses dois modos de investigação.
} 
Ela se caracteriza como pesquisa participativa, aproximando-se da pesquisa-ação (apresentada na seção anterior). Para situar a pesquisa-intervenção de modo breve, pode-se dizer que ela resulta de reflexões propositivas provindas de diversas/os pensadoras/es, agregadas/os em torno das filosofias da complexidade ou das diferenças, que refletem sistematicamente sobre a temática da neutralidade, imposta aos sujeitos pesquisadores e às/aos pesquisadas/os no ato de produção de uma pesquisa científica, filosófica e educativa. Afirmam que, na ação de pesquisar, há o acesso, pelas/os pesquisadoras/es e pessoas participantes, a uma gama de elementos subjetivos, inconscientes, com sentidos e teorias implícitas (MORAES; GALIAZZI, 2016). Assim, há uma provocação para visitar e revisitar as complexidades dos fenômenos sociais, como o educacional, que recoloca o senso comum como elemento constitutivo nas produções científicas, pois ele se configura como o menor denominador comum "daquilo em que um grupo ou um povo coletivamente acredita" (SANTOS, 1989, p. 37) e que estão presentes em todas as etapas da produção científica, educacional e filosófica.

Nesse sentido, diferenças e conceitos que circundam o senso comum são riquezas e vantagens no universo educativo por promoverem "processos sistemáticos de diálogo entre diversos sujeitos - individuais e coletivos -, saberes e práticas na perspectiva da afirmação da justiça - social, econômica, cognitiva e cultural" (CANDAU, 2016, p. 808). Os sujeitos de conhecimento (pesquisadoras/es e pessoas participantes) elaboram, de modo distinto, seus saberes. Essa elaboração, ao ser considerada na construção educacional, faz com que esses sujeitos se percebam incluídos como seres distintos. Essa inclusão se traduz em justiça, por oportunizar diferentes modos de produção e acessos aos conhecimentos elaborados por toda a humanidade, incluindo os saberes considerados "marginais", como os indígenas, africanos e ciganos, entre outros.

Com esses esforços na elaboração e produção de conhecimentos contextualizados e intersubjetivos, situados historicamente, a pesquisa-intervenção, dentro do campo da pesquisa educacional participativa, pontua a relação "dentro/fora" como uma problemática nos espaços escolares. Isso porque as escolas, na maioria das vezes, são apenas percebidas como um lugar de aprendizagens formais, estabelecendo pouca ou nenhuma conexão com as experiências e com o cotidiano que estão "fora" delas. Os elementos "fora" das escolas são aqueles que permeiam a vida de estudantes e da comunidade onde convivem (ROCHA; AGUIAR, 2003). Logo, estão "dentro" da 
escola, mas, por vezes, não são levados em conta nos processos de ensinoaprendizagem, nem na maioria das pesquisas.

Ao perceberem-se essas conexões, acentuam-se relações de reciprocidade (MACHADO, 1990; MARASCHIN, 2004) entre escolas e comunidades, educação e sociedade. Ao não realizarem essas conexões, as pessoas que estão dentro das escolas, em sua maioria, fomentam discursos e práticas "que transmutam as desigualdades sociais em dificuldades individuais" (SOUZA; VIOTTO FILHO, 2018, p. 107). Sendo assim, a pesquisa-intervenção problematiza esses discursos e essas situações "acomodadas no interior da escola" (BONAMIGO et al., 2014, p. 522).

A partir de tais características, fica evidente que "ntervenção" não é uma postura de investigação impositiva, mas uma busca de articulação de contextos das vivências escolares com aqueles considerados não escolares, nos quais estudantes e professoras/es estão imersas/os. Não é apresentação de uma "receita pronta" que será testada em um ambiente controlado por especialistas externas/os. Ao contrário, é um mergulho das/os pesquisadoras/es "dentro e fora" das naturalizações, acomodações e complexidades engendradas em si mesmas/os e nos diversos ambientes escolares.

A pesquisa-intervenção acentua as dimensões da subjetividade como condição do próprio conhecimento (COUTINHO, 2011; POCAHY, 2016), como também da micropolítica do cotidiano enquanto processos de singularização (ROCHA; AGUIAR, 2003; PAULON, 2005). Com isso, a atenção volta-se aos conhecimentos sobre o que pensam/vivenciam estudantes, professoras/es e demais pessoas que dão vida aos ambientes escolares. Por isso, a pesquisa-intervenção pode proporcionar a criação de espaços, dentro e fora das escolas, para repensar laços micro e macrorrelacionais, por meio de discussões em grupo (COUTINHO, 2011). Os grupos de discussões podem favorecer convivências cotidianas entre pesquisadoras/es e pessoas pesquisadas.

Com tais elementos, é possível definir a pesquisa-intervenção como uma investigação da "vida da coletividade em sua diversidade qualitativa, assumindo uma intervenção de caráter socioanalítico" (ROCHA; AGUIAR, 2003, p. 67). Afirmam-se as realidades como junção de aspectos sociais, políticos e culturais, entre outros, que formam microrrelações que precisam ser analisadas durante o processo de pesquisa. Isso aponta que a intervenção é um modo de pesquisa em que se quer "compreender um sistema de vida, seus múltiplos e heterogêneos modos de constituição e a recorrência de sua produção" (MARASCHIN, 2004, p. 101). Pesquisadoras/es que optam pela 
pesquisa-intervenção são provocadas/os a compreender os ambientes escolares como microssistemas interconectados de questões macro/micropolíticas e culturais.

Portanto, a pesquisa-intervenção não tem etapas, mas critérios de escolha dos procedimentos metodológicos. Um deles é a promoção de participação ativa dos sujeitos da pesquisa (POCAHY, 2016; SOUZA; VIOTTO FILHO, 2018), que tanto são as/os pesquisadoras/es quanto as pessoas pesquisadas. Outro critério é a prática desnaturalizada, que almeja compreender a "rede de poder e o jogo de interesses que se fazem presentes no campo da investigação, colocando em análise os efeitos das práticas no cotidiano institucional, desconstruindo territórios e facultando a criação de novas práticas" (ROCHA; AGUIAR, 2003, p. 71). Por isso, as escolhas e decisões são uma "contínua reformulação da experiência com a experiência" (MARASCHIN, 2004, p. 106) e "articulação constante entre a ação desenvolvida por um grupo e o conhecimento que dela se depreende" (PAULON, 2005, p. 20). As decisões dos procedimentos devem estar integradas e ser realizadas pelas/os pesquisadoras/es, mediante seu objeto de pesquisa, com diálogos contínuos com as pessoas envolvidas no processo de investigação, que podem provocar mudanças tanto nas decisões quanto nos procedimentos.

\section{As peneiradas nas dissertações do PROF-FILO impulsionadas pela ATD}

Diante da breve explanação epistemológica de cada tipo de pesquisa que circula nas 76 dissertações autoafirmadas como qualitativas, apresentaremos, neste tópico, as interpretações descritivas que compõem nossas análises sobre o corpus investigado, ou seja, as sete dissertações que apresentaram uma "lógica interna da pesquisa" (GAMBOA, 2012, p. 58) alinhada, de modo explícito, em suas escolhas epistemológicas e metodológicas, com a inserção no campo empírico de pesquisa. De acordo com a ATD, este momento, que se configura como nossa terceira peneirada, torna-se etapa de formulação do metatexto que propicia outros olhares e compreensões no "exercício de produção de novos significados" (MORAES; GALIAZZI, 2016, p.117) como discurso articulado que favorece maior fidedignidade ao corpus analisado (ROJAS et al., 2010). 


\subsection{Pesquisa Fenomenológica - caminho de compreensão do ensino e da prática do filosofar no mundo vivido}

As duas dissertações que se conduziram na pesquisa fenomenológica coadunamse com os critérios apontados no terceiro momento de nossas peneiradas. As dissertações são: a) "Ensino de filosofia no ensino médio: contributos da Fenomenologia para a prática docente", e b) "O ensino de Filosofia: um diálogo com a educação interdimensional na formação de um jovem solitário, autônomo e competente". Os respectivos autores são: a) Geyson Magno Tôrres Monteiro; b) José Gilberto da Silva. Ambas as dissertações foram defendidas no PROF-FILO da Universidade Federal de Pernambuco (UFPE), na cidade de Recife, no ano de 2019.

As dissertações analisadas foram sinalizadas por meio dos seguintes códigos: MONTEIRO, (2019) e SILVA, (2019). A partir das leituras orientadas pela ATD, organizamos as unidades de significados, os títulos, as categorias iniciais e as categorias finais/emergentes tendo como pano de fundo a vigilante indagação: "o que é isso que se mostra de pesquisa fenomenológica nas pesquisas qualitativas do PROF-FILO?”. Desse modo, desvelaram-se as seguintes categorias: a) o significado da fenomenologia e a sua relevância para a compreensão do fenômeno pesquisado e o exercício do filosofar; b) método fenomenológico enquanto uma abertura de interrogação e compreensão do mundo; c) a coleta de dados constituída pela entrevista de viés fenomenológico e o seu alcance; d) os conhecimentos constituídos na aplicação do método fenomenológico no desenvolvimento da pesquisa; e) as posturas epistemológicas assumidas pelas/os pesquisadoras/es na vivência da pesquisa alicerçadas na perspectiva fenomenológica; e f) o lócus no qual se constitui a compreensão das essências do fenômeno que se mostra para a/o pesquisadora/or e os sujeitos da pesquisa. Essas categorias estão apresentadas abaixo.

\subsubsection{O significado da fenomenologia e a sua relevância para a compreensão do fenômeno pesquisado e o exercício do filosofar}

No decorrer do exercício de unitarização e categorização, o sentido que se mostrou comum a Silva (2019) e Monteiro (2019) foi o da compreensão do conceito e do fazer da pesquisa fenomenológica. Percebemos que ambos, ao constituírem e vivenciarem os passos de seus caminhos metodológicos, apreenderam um sentido muito 
próximo do significado da fenomenologia e da compreensão de sua relevância para atingir a essência dos fenômenos pesquisados. Segundo Silva (2019),

a fenomenologia procura ir à essência do fenômeno buscando respostas claras e significativas. Fez-se, então, necessário estar dentro do processo para compreender os significados dos símbolos e perceber quais e quem são esses símbolos e ao mesmo tempo estar fora, para se ter percepção e ver como a percepção se faz através dos símbolos que refletem a consciência dos estudantes (p. 37-38)

Semelhante posição assume Monteiro (2019) ao afirmar que

o objetivo metodológico é trazer à vida escolar uma Fenomenologia enquanto uma tentativa de descrição do fenômeno educativo de uma forma mais modesta, mas, o mais rico possível, que dê a devida atenção ao processo coletivo que é a educação e ao devir sujeito, sendo esse sujeito a concretude de um projeto aberto de homem (p. 77).

Tais compreensões atribuem sentido à fenomenologia como uma abordagem filosófica que possibilita o filosofar por meio dos textos mediatizados pela possibilidade de diálogo entre as/os pesquisadoras/es e o sujeito da pesquisa.

A base teórica dos pesquisadores é muito aproximada, na medida em que estudam: Husserl, Maria Aparecida Viggiani Bicudo, Angela Ales Bello e MerleauPonty. Por isso, a fenomenologia apresenta-se como uma epistemologia do olhar e da escuta, privilegiando o ouvir, o diálogo e o silêncio, que pode ser entendido como aquele que é anterior à fala na dimensão da temporalidade. Outra aproximação é a percepção da fenomenologia enquanto ontologia do sentido no âmbito do desenvolvimento da prática educativa e do método, que é considerado como uma forma radical de pensar. A fenomenologia é compreendida, por ambos os autores, como um método que possibilita às/aos pesquisadoras/es, como também ao sujeito da pesquisa, dirigirem-se à compreensão da essência do fenômeno mediante dois movimentos: o de estar dentro do fenômeno para compreender os seus significados simbólicos e, com isso, perceber a essência desses símbolos, e fora, para alcançar a percepção do reflexo desses símbolos nos sujeitos da pesquisa.

\subsubsection{Método fenomenológico enquanto uma abertura de interrogação e compreensão do mundo}

Essa categoria mostrou-se ao percebermos que Monteiro (2019) e Silva (2919) compreenderam, de forma similar, que a metodologia fenomenológica se constitui como uma abertura para o mundo como um modo de interrogá-lo. Dessa forma, é pertinente apontar que, para Monteiro (2019, p.75), 
A metodologia utilizada como referência para a pesquisa e intervenção prática na escola é de matriz fenomenológica, sobretudo na Fenomenologia da corporificação de Merleau-Ponty, mais precisamente, o conteúdo teórico da obra Fenomenologia da percepção. Nessa fenomenologia defendida pelo filósofo, não há fechamentos, pois, estar no mundo é compreendido como um interrogá-lo.

Do mesmo modo, afirma Silva (2019, p. 38) que

\begin{abstract}
A fenomenologia, ao ser analisada como um método de pesquisa, "é uma forma radical de pensar" (MARTINS; BICUDO, 1983, p. 11). Como a pesquisa quis ver, na experiência do estudante, reveladas as transformações como ser pensante, que reflete sobre suas condições e as relacionam com os outros ao seu redor e o mundo que os cercam, vê, portanto, no método fenomenológico tais garantias, na medida em que procura ver as coisas como se mostram para caracterizar o ser em sua unidade essencial e básica. É nesse contexto que as relações entre o pesquisador e o pesquisado se entrelaçam, por validar o captado da intensidade da voz, do dito nas entrelinhas e o testemunhado pelo pesquisador sobre as transformações ao longo do processo educativo dos educandos.
\end{abstract}

Para os dois autores, a fenomenologia mostra-se como método de pesquisa que, ao valorizar o objeto de estudo como sujeito do conhecimento, conduz a ontologia do sentido, na qual a noção de situação se contrapõe à epistemologia da objetividade. As suas falas vão nessa direção, na medida em que ambos concordam que a fenomenologia, como método, possibilita a descrição do fenômeno educativo em que se mostra o devir do sujeito como um projeto aberto.

O método fenomenológico foi vivenciado, por ambos os autores, como um caminho seguro de apreender o sentido do fenômeno através do olhar, ou seja, do ato de ver as coisas que se mostram diante das/os pesquisadoras/es e dos sujeitos da pesquisa, assim se caracterizando o ser em sua unidade essencial e básica. Em comum, há o entendimento de que o sentido do método fenomenológico se vivencia em três momentos: a redução, a descrição e a interpretação, cuja finalidade é atingir o fenômeno (BICUDO, 2011; BELLO, 2006). No processo de redução e interpretação do método, ocorrem dois processos de análise: o de análise ideográfica e análise psicológica individual; e o de análise ideográfica geral e análise nomotética (BICUDO, 2011).

Dessa forma, o que se mostrou de compreensão emergente nos dois autores das dissertações investigadas é que o método fenomenológico possibilitou apreender o fenômeno estudado, vivenciado pelos sujeitos da pesquisa, no âmbito do ensino de filosofia no decorrer do processo ensino/aprendizagem. 


\subsubsection{A coleta de dados constituída pela entrevista de viés fenomenológico e o seu alcance}

Silva (2019) e Monteiro (2019) comungam da compreensão de que a escuta no processo da coleta de dados, na dimensão fenomenológica, é o caminho da percepção da temporalidade dos fenômenos no seu desvelar. Isso tornou os pesquisadores sensíveis à compreensão do sentido do fenômeno. Os pressupostos fenomenológicos, no que diz respeito às informações coletadas e experiências vividas no ensino de filosofia no chão da escola, possibilitaram a compreensão da contribuição de ambos para o ensino de filosofia, na medida em que buscaram olhar para a essência de cada sujeito implicado na pesquisa.

Em ambos os textos, no âmago de suas reflexões, mostra-se a ideia de que, no processo de entrevistas que se fundamentam na perspectiva fenomenológica, à medida que surgem as interrogações, elas remetem ao sentido das práticas e das vivências, pois, como diz Silva (2019, p. 39),

a utilização de entrevistas proporcionou uma interação social entre o entrevistador e os entrevistados o que garantiu maior qualidade dos dados. Tais entrevistas foram semiestruturadas por permitirem maior alargamento da obtenção de informações a partir da dinâmica interativa entre o pesquisador e os alunos. Um dos objetivos foi a investigação dos fenômenos, ou seja, conhecer se os envolvidos que têm as informações são capazes de compreendê-las. Além disso, as entrevistas captaram as opiniões sobre os fatos; a determinação de sentimentos; a descoberta de planos de ação e inclusive os motivos conscientes que podem influenciar opiniões, sentimentos, sistemas ou condutas.

\section{Monteiro (2019, p. 76) argumenta que}

nosso trabalho parte de uma epistemologia do olhar ampliando-se a uma epistemologia da escuta que privilegia o ouvir e um diálogo pautado por um silêncio que antecede uma fala. Ao estarmos em escuta estamos inseridos na temporalidade dos fenômenos, nos envolvendo na ordem do aparecimento e desenvolvimento dos fenômenos que nos tornamos sensíveis.

A compreensão da entrevista como coleta de dados que diz respeito a uma escuta compartilhada entre o pesquisador e o sujeito da pesquisa, também percebida como acolhida do desvelamento da essência do fenômeno e da compreensão dos sujeitos da pesquisa sobre o fenômeno que se revela diante do olhar das/os pesquisadoras/es. Dessa forma, a entrevista de viés fenomenológico semiestruturada tornou-se escolhida, na coleta de dados, por possibilitar uma maior interação entre as/os pesquisadoras/es e os sujeitos da pesquisa no decorrer da compreensão do fenômeno investigado. 


\subsubsection{Os conhecimentos constituídos na aplicação do método fenomenológico no desenvolvimento da pesquisa}

O que se mostrou, com essa categoria, é que os autores atingiram a compreensão de que, com a aplicação do método fenomenológico, se podem constituir conhecimentos novos, pois a verdade científica é uma expressão do mundo vivido e da sua natureza enquanto uma hermenêutica da facticidade e da ontologia do presente. Dessa forma, diz Silva (2019, p. 39) que

a fenomenologia procura ir à essência do fenômeno buscando respostas claras e significativas. Fez-se, então, necessário estar dentro do processo para compreender os significados dos símbolos e perceber quais e quem são esses símbolos e ao mesmo tempo estar fora, para se ter percepção e ver como a percepção se faz através dos símbolos que refletem a consciência dos estudantes.

Na mesma direção, afirma Monteiro (2019, p. 76) que

toda a verdade científica está construída sobre o mundo vivido e sua Natureza, sendo ela expressão desse mundo, devendo ser considerada como expressão desse mundo, numa hermenêutica da facticidade, sendo dessa forma, não normativa, uma ontologia do presente que necessita de uma ação contínua, de um fazer do trabalho enquanto algo inato do ser humano e fazerse sempre e de uma compreensão de experiência nas relações com o mundo da vida ativa.

Na percepção de ambos os pesquisadores, para a verdade ser constituída no processo de elaboração dos dados coletados, o viés fenomenológico configura-se como uma ontologia do presente do fazer compreensivo do ser humano mediante as suas relações com o mundo em sua vida ativa. Nesse sentido, os textos produzidos são percebidos como uma reinterpretação e reelaboração dos fenômenos, ou seja, dos conhecimentos experienciados tanto pelo pesquisador/a quanto pelos sujeitos da pesquisa. Esse sentido atribuído ao método fenomenológico como aquele que possibilita a constituição de novos conhecimentos foi relevante para os autores dos textos analisados.

\subsubsection{As posturas epistemológicas assumidas pelo pesquisador/a na vivência da pesquisa e alicerçadas na perspectiva fenomenológica}

Para ambos os pesquisadores, desvelou-se o sentido das posturas epistemológicas que assumiram durante a vivência de suas respectivas pesquisas. Essas são constituídas nas vivências nas etapas de aplicação do método fenomenológico. Silva (2019, p. 41) afirma que, 
como o pesquisador fez e faz parte do processo, o olhar que este tem também foi significativo, uma vez que que ele faz parte e investiga o fenômeno ao mesmo tempo. Nessa perspectiva, a própria experiência do pesquisador foi tomada como referência e isso foi avaliado a partir do olhar do jovem, participante do processo.

As posturas epistemológicas são vivenciadas pelo pesquisador/a no transcorrer da pesquisa através do seu olhar. Isso é considerado como algo significativo, porque, no momento em que esse olhar se volta para o fenômeno pesquisado, o pesquisador/a interage no interior da vivência do fenômeno pesquisado. Para Monteiro (2019), a postura epistemológica que deve ser assumida pelo pesquisador/a diz respeito ao seu envolvimento com o mundo da vida, já que, "nesse envolver-se com as coisas enquanto uma experiência que nos toca, que nos perpassa, estabelece-se um conhecer, um saber que não se dá apenas no acontecimento do fenômeno, mas se instala também no passado, na esfera do mundo da percepção" (p. 76).

A postura epistemológica assumida pelos dois pesquisadores tem relação com o envolvimento perceptivo com o mundo e com os sujeitos da pesquisa de forma imediata pelo crivo da intersubjetividade. Mediante tal postura, vivencia-se a experiência perceptiva do fenômeno passado, que toca e perpassa o pesquisador/a e o sujeito da no trajeto da pesquisa, possibilitando o conhecimento do mundo fenomênico.

\title{
4.1.6 O lócus no qual se constitui a compreensão das essências do fenômeno que se mostra para o pesquisador/a e os sujeitos da pesquisa
}

Um dos autores expressou-se sobre o lócus de constituição da pesquisa da seguinte maneira:

\begin{abstract}
a escola é o espaço e o alvo da intervenção e se apesar de ser, o professor da escola, o primeiro atingido, articula e supera o seu conhecimento, sua conduta e ação em comunidade, no agir com o outro, inicialmente a comunidade de convívio dentro da escola, profissionais da educação em todas as suas especificidades e os alunos e posteriormente com a comunidade que se expande da escola. Partindo da escola é possível ter poder de narrar e interpretar tanto a Filosofia, quanto a fotografia por sua objetividade (MONTEIRO, 2019, p. 77).
\end{abstract}

A escola é compreendida por esse autor como o lócus que possibilita a narração e a interpretação da filosofia. Ele ressalta a relevância do estudo da filosofia por meio da fotografia para atingir a essência do acontecimento, assim se constituindo o conhecimento reflexivo. A escola é entendida pelo pesquisador como o lócus de poder de narração e interpretação da essência do acontecimento do ensino de filosofia, que é possível experienciar no ato de fotografar. 
Para Silva (2019, p. 37),

convém salientar, com base nos pressupostos fenomenológicos, que as informações coletadas e experiências vividas no universo ETE Cícero Dias, no que diz respeito à prerrogativa de que o Ensino de Filosofia tem contribuído para uma formação humana, busque a "essência" de cada sujeito envolvido na pesquisa, objetivando caracterizar o que permeia o pensamento e as atitudes dos envolvidos.

Dessa forma, o que surgiu como categoria emergente é que, para ambos os pesquisadores, a escola é compreendida como o lócus de constituição dos fenômenos da pesquisa. É uma instituição social onde é possível compreender a essência dos sujeitos da pesquisa ao investigar-se como, nessa instituição, é vivenciada a essência do acontecimento do ensino de filosofia.

\subsection{A pesquisa-ação como investigação do saber-fazer no ensino de filosofia}

Após desenvovimento das categorias alusivas à pesquisa fenomenológica, vamos adentrar na análise das duas dissertações, no que se refere aos critérios elencados no terceiro momento de nossas peneiradas no percurso metodológico da pesquisa-ação. As dissertações - produzidas por um pessoa do gênero feminino e outra do gênero masculino - são as seguintes: a) "Ensinar e aprender filosofia numa perspectiva ética: uma proposta de intervenção numa escola pública", defendida no PROF-FILO da Universidade Federal do Piauí (UFPI), na cidade de Teresina, no ano de 2019; b) "Nietzsche e o ensino de filosofia: uma metodologia para o ensino médio", defendida no PROF-FILO da Universidade do Estado do Rio Grande do Norte (UERN), Campus Caicó, também em 2019.

As dissertações - sinalizadas pelos códigos ARAÚJO, 2019 e SOARES JÚNIOR, 2019 - configuram-se como experiências potentes da pesquisa na/pela prática docente de professoras/es de filosofia que investigam processos de ensinar-aprender na mediação didática com as/os estudantes do Ensino Médio. Com as leituras orientadas pela ATD, organizamos as unidades de significados, os títulos, as categorias iniciais e categorias finais/emergentes tendo como pano de fundo a indagação: "o que é isso que se mostra de pesquisa-ação nas pesquisas qualitativas do PROF-FILO?”. Surgiram as seguintes categorias emergentes: a) as subjetividades como dados da pesquisa no ensino de filosofia; b) a pesquisa-ação como pesquisa coletiva no ensino-aprendizagem da filosofia; c) a prática docente como lugar de pesquisa; d) as transformações na prática pedagógica pela pesquisa-ação. A seguir, apresentamos essas categorias. 


\subsubsection{As subjetividades como dados da pesquisa no ensino de filosofia}

$\mathrm{Na}$ compreensão do que se apresenta como categoria emergente no corpus investigado, a subjetividade demarca uma concepção qualitativa do fazer pesquisa. Desse modo apresenta-se, assim, a subjetividade como princípio proeminente na pesquisa qualitativa, especialmente no uso da pesquisa-ação no/sobre o ensino de filosofia.

Soares Júnior (2019), em sua dissertação, afirma que, em uma pesquisa de natureza qualitativa, a/o pesquisadora/or, ao inserir-se em campo, tem contato com os aspectos mais subjetivos dos sujeitos. Conforme aponta o autor, em sala de aula, a partir da pesquisa qualitativa, é possível "fazer reflexões sobre os fatos da vida real dos alunos e seus significados" (p. 89), de modo que é significativa a aparição das subjetividades no desenvolvimento da pesquisa. As subjetividades que se mostram nessa dissertação foram elucidadas enquanto "múltiplas visões" (p. 89) que possibilitam uma melhor compreensão e análise do problema investigado.

Araújo (2019) parte da construção argumentativa do desenvolvimento de uma pesquisa qualitativa, apresentando-nos em seu texto uma concepção de integração das subjetividades articuladas e estimuladas pelo problema filosófico. A dissertação aponta uma definição de pesquisa qualitativa, enfatizando a importância dessa abordagem para suscitar as subjetividades compostas nas "motivações não explícitas, ou mesmo conscientes, de maneiras espontâneas" (p. 60), a partir da relação que a/o pesquisadora/or tem com seu lugar de pesquisa e os sujeitos participantes, compreendendo a participação a partir do "livre pensamento" (p. 60).

A potencialidade das subjetividades como elementos constituintes nas pesquisas qualitativas, desenvolvidas na relação cooperativa que a pesquisa-ação possibilita, nos é apresentada nessas dissertações por meio dos dados apresentados por cada pesquisa em questão. Isso fortalece a ideia, conforme aponta González (2001), de que as pesquisas qualitativas que, além da natureza qualitativa, assumem os pressupostos epistemológicos qualitativos levam em conta o caráter construtivo-interpretativo, dialógico e atento às singularidades e subjetividades daquelas/es envolvidas/os com a pesquisa. 


\subsubsection{A pesquisa-ação como pesquisa coletiva no ensino-aprendizagem da filosofia}

Observamos a recorrência de afirmativas que relacionam a pesquisa-ação a uma concepção e prática de pesquisa que não se efetiva unicamente a partir da experiência e análises das/os pesquisadoras/es, mas que integra as pessoas participantes no engajamento interessado para o desenvolvimento e resolução do problema elencado coletivamente. Soares Júnior (2019) afirma que a pesquisa-ação potencializa o campo empírico, possibilitando o encontro dialógico entre pesquisadora/or e participantes na experiência da pesquisa, das situações propostas, vivenciando a "interação numa plena relação com o problema em questão" (p. 90).

Segundo Franco (2005, p. 496), a pesquisa-ação aponta para a "concomitância entre pesquisa e ação e ação e pesquisa", sugerindo, inclusive, que a terminologia "deveria ser expressa em forma de dupla flecha, ao invés de hífen: pesquisa $\leftrightarrow$ ação", para dar visibilidade maior à inter-relação que compõe a pesquisa, tendo como principais características "a concomitância, a intercomunicação e a interfecundidade".

Ambas as dissertações acionam termos como "conjuntamente" e "interação" ao referirem-se ao modo como foi abordada a pesquisa na relação com as pessoas participantes, corroborando o pensamento de Thiollent (2011, p. 75), que retifica a ação como parte da concepção de produção de conhecimento nesse tipo de pesquisa. Especialmente no campo educativo, essa ação não pode ser constituída somente de descrição e avaliação, fazendo-se necessário o envolvimento sistemático das/os pesquisadoras/es desde a formulação até o alcance dos objetivos elencados.

Segundo Araújo (2019, p. 90), na pesquisa-ação, “pesquisador e pesquisados encontram-se conjuntamente dentro do mesmo problema que envolve o ensino da filosofia", reiterando a implicação dessa metodologia de pesquisa como potencialidade a ser desenvolvida no ambiente escolar. Conforme afirma Franco (2012), isso requer estratégias pedagógicas para construir dinâmicas que potencializam a relação docentediscente como sujeitos articulados em torno do(s) problema(s) que se mostra(m) na pesquisa. Desse modo, as dissertações chamam atenção para a oportunidade de professoras/es pesquisarem suas práticas, enfatizando que o âmbito educacional está imbuído de coletividades, o que potencializa a realização de pesquisa como a pesquisaação. 


\subsubsection{A prática docente como lócus epistemológico da pesquisa-ação}

Aparece-nos como elemento recorrente, nas dissertações de Araújo (2019) e Soares Júnior (2019), a compreensão da pesquisa realizada a partir da prática docente como caminho didático que fortalece a identidade da/do professora/or pesquisadora/or. A prática docente mobiliza - além de um campo de investigação e estudos da Pedagogia e da Didática - o chão da escola onde pisa e age a/o professora/or. É na prática docente que os saberes advindos da formação e os saberes da prática se articulam no saber-fazer docente.

Araújo (2019) evidencia a importância da pesquisa na prática docente, enfatizando como a pesquisa-ação possibilita aportes para a "prática metodológica do professor, contribuindo para uma maior interação entre os sujeitos envolvidos na busca de soluções para o problema posto em questão" (p. 60). Com esse mesmo entendimento, Soares Júnior (2019, p.118) afirma que, na pesquisa-ação, “o professor pesquisador também é sujeito participante na ação da pesquisa e sua percepção/observação é também elemento/instrumento que compõe o campo avaliativo sobre os resultados".

Conforme aponta Franco (2012), a pesquisa-ação associada à investigação da prática docente por professoras/es constitui-se como instrumento pedagógico de empoderamento docente, reafirmando os sujeitos no campo epistemológico como sujeitos que não somente socializam conhecimentos, como também os produzem. Araújo (2019, p.63) entende que todo o processo de pesquisa, desde questões problematizadoras, "bem como o alinhamento das ações que culminaram com a prática pedagógica na sala de aula”, nos revela o entendimento da perspectiva coletivopedagógica que constitui princípios para a realização da pesquisa-ação, especialmente no âmbito escolar.

\subsubsection{As transformações na prática pedagógica pela pesquisa-ação}

A compreensão da transformação como pressuposto da pesquisa-ação é evidenciada nas análises das dissertações em questão. Compreendida não consensualmente entre autoras/es da pesquisa-ação, a transformação é uma questão de múltiplas abrangências. Conforme afirma Soares Júnior (2019, p. 91) em sua dissertação, a pesquisa-ação, a partir da sistematização do planejamento participativo e da problemática elencada, visa a "transformar as realidades", implicando também "mudanças de comportamento e de atitudes de pesquisador e pesquisados" e reforçando 
o "compromisso para com as ações e o que se pretende propriamente na pesquisa". Para o autor, há uma compreensão de transformação que perpassa, inclusive, as ações e os comportamentos das pessoas participantes e de pesquisadoras/es. Isso possibilita compreender que a "realidade" a ser transformada inclui o cotidiano escolar no qual elas/eles também se encontram inseridas/os. Araújo (2019) também compreende a transformação como elemento da pesquisa e, especialmente, como elemento da filosofia, haja vista que, para a autora, a "transformação da realidade escolar" (p. 13), mediada pela transformação de valores morais e éticos, constitui elemento mobilizador significativo para pesquisas voltada ao ensino de filosofia.

Thiollent (2011, p.49) diz que o "alcance das transformações" se torna um

alerta, por apontar a pretensão dessa abordagem metodológica na direção da abrangência de sua realização empírica de pesquisa enquanto alcance de "realizações, ações efetivas, transformações ou mudanças no campo social", de modo que a concepção de transformação varia conforme os pressupostos da pesquisa.

\subsection{Pesquisa-intervenção e as desnaturalizações referentes ao ensino de filosofia}

Mediante as categorias provindas da análise do que se mostra da pesquisa fenomenológica e da pesquisa-ação, adentramos nas três dissertações que se autoafirmaram como pesquisa-intervenção ou "pesquisa de intervenção filosófica", com o auxílio da ATD. São elas: "A problematização filosófica como paradigma da construção do pensamento complexo: uma proposta curricular de intervenção", defendida por pessoa do gênero feminino no PROF-FILO da Universidade Federal do Piauí (UFPI), na cidade de Teresina, em 2019; "Indústria cultural x conceito-imagem em Adorno e Cabrera: Uma proposta de intervenção a partir do uso de cinema no Ensino de Filosofia", apresentada por pessoa do gênero feminino no PROF-FILO da Universidade Federal de Pernambuco (UFPE), na cidade do Recife, no ano de 2020; e "Educação estética em Marcuse: Avaliação em filosofia para além do textual”, escrita por pessoa do gênero masculino e defendida no PROF-FILO da Universidade Federal do Tocantins, na cidade de Palmas, em 2019.

As dissertações analisadas neste tópico são indicadas pelos códigos: SILVA, 2019, SOUZA, 2020 e OLIVEIRA, 2019. Elas abordaram a área de Ensino de Filosofia a partir da aproximação da prática docente e do aprender-ensinar filosofia no Ensino Médio. Com as leituras orientadas pela ATD, em uma terceira peneirada, perseguimos a 
questão: "o que é isso que se mostra de pesquisa-intervenção ou 'pesquisa de intervenção filosófica' nas pesquisas qualitativas do PROF-FILO?’. Os movimentos da terceira peneirada indicaram-nos as seguintes categorias: a) apreensões de pesquisaintervenção ou "pesquisa de intervenção filosófica"; b) avaliação como problema filosófico; c) práticas pedagógicas dentro e fora do ensino de filosofia; d) filosofar com a vida cotidiana de estudantes; e e) multimodos para tratar o ensino de filosofia. Essas categorias são tratadas logo adiante.

\subsubsection{Apreensões de pesquisa-intervenção ou "pesquisa de intervenção filosófica"}

A primeira categoria, "apreensões da pesquisa-intervenção", aparece na dissertação de Silva (2019) como concepção de intervenção filosófica com as características de "crítica, reflexiva e transformadora" (p. 56). Por isso, seu problema central, que é a inter/transdisciplinaridade, é concebido como "fenômenos complexos, pois esses são de uma multiplicidade de interpretações e sentidos atribuídos à realidade" (SILVA, 2019, p. 63-64) escolar. A autora não se refere apenas ao ensino de filosofia, mas também ao modo como os componentes curriculares, incluindo a Filosofia, estão dispostos e, na maioria das vezes, reforçam um ensino reducionista.

A dissertação defendida por Souza (2020) define-se como pesquisa-intervenção por estar focada nas colocações de estudantes enquanto "apreensões mais subjetivas, que prescindem, por sua vez, de dados numéricos e estatísticos" (p. 53). A autora apresenta um trabalho pedagógico com três filmes: O Show de Truman, Central do Brasil e Mulher Maravilha, intercalando aulas expositivas com debates contextualizados, textos escritos e produções de vídeos.

O que se mostra de pesquisa-intervenção, ou pesquisa de intervenção filosófica, na dissertação de Oliveira (2019) é o modo de abordar o problema da avaliação enquanto elemento situado em um sistema lógico perverso de repressão que, em um processo de desacomodação, pode ser apreendido como "instrumento de aprendizagem formativa e qualitativa em prol da emancipação humana" (p. 43). O autor evidencia sua experiência histórica de docente de Filosofia no Ensino Médio, relacionando subjetividade e intersubjetividade, ao afirmar a necessidade da "intencionalidade ética, política e estética (...), isto é, preciso filosofar sobre um problema que identifiquei e que busquei solucionar enquanto professor e pesquisador" (OLIVEIRA, 2019, p. 50). 
Mesmo não havendo uma definição evidente de pesquisa-intervenção, o modo metodológico de tratar os objetos de pesquisa presentes nas três dissertações aponta na direção da desacomodação, da inter/subjetividade e da micropolítica do cotidiano no ensino de filosofia. O que está posto nas dissertações como movimento de "transformar" os lugares "conhecidos" (ROCHA; AGUIAR, 2003) da filosofia no Ensino Médio resulta em outras questões para esse mesmo ensino. Com isso, abrem-se peneiradas de problemáticas que a pesquisa-intervenção proporciona, com enfrentamentos singulares para o ensino de filosofia como área de pesquisa filosófica.

\subsubsection{Ensino de filosofia e as avaliações como problema filosófico}

As peneiradas direcionaram-nos para a segunda categoria - avaliação como problema filosófico. Oliveira (2019) relata sua vivência de avaliação como algo inquietante, pois "não queria fazer ninguém passar por uma situação constrangedora como aquela e que, na minha visão, era desnecessária, mas eu precisava atribuir uma nota para cada estudante" (p. 54). Ele afirma a avaliação como unidimensional, causadora de constrangimento e violência, centrada nos conteúdos organizados pelo livro didático, que devem apenas ser repetidos por estudantes. O que significa avaliar, então? O autor aponta que as avaliações revelam "pequenas hierarquias que levam a sistemas hierárquicos maiores: da sala de aula para a escola, da escola para a secretaria de educação, da secretaria de educação para o Estado, do Estado para o Mercado e assim por diante" (OLIVEIRA, 2019, p. 48). Essas hierarquias escondem/mostram um sistema de notas mantenedor de desigualdades. Esse sistema revela-se nas pequenas humilhações e indiferenças, como forma de exclusão de estudantes consideradas/os desajustadas/os, e nas falas atenciosas e nos elogios, como ascensão para aquelas/es que são consideradas/os merecedoras/es e preparadas/os. Aqui se observa uma relação de poder (PAULON, 2005) microssituada de dominação por meio do processo avaliativo como instrumento de punição.

Ao aprofundar a indagação sobre sistemas microssituados de relação de poder punitivo, Silva (2019) afirma que a maneira de professoras/es aprenderem a ensinar, historicamente, "esteve atrelada a uma formação fragmentada e especializada, vinculada ao modelo da racionalidade técnica, cientificista, em que o sistema, para atender às suas demandas, vê o professor como um técnico a desempenhar funções desejadas" (p. 74). Nesse formato, tal relação de poder se reproduz em todo o sistema educativo, inclusive 
no âmbito da avaliação, por isso o "desafio de implementar, na proposta curricular, eixos problematizadores que possam viabilizar (...) a promoção de uma formação autônoma e cidadã dos discentes" (SILVA, 2019, p. 75). Se as/os docentes forem mobilizadas/os dentro de problematizações inter e transdisciplinares, pode-se obter uma percepção das consequências de mecanismos violentos, não apenas na avaliação, mas no modo de ensinar e aprender (BONAMIGO et al., 2004), presentes em todos os componentes do currículo da educação básica e, quiçá, no processo formativo de professoras/es no Ensino Superior.

\subsubsection{Ensino de filosofia: práticas pedagógicas dentro e fora do ensino de filosofia}

O desacomodar dos significados diários e comuns das avaliações, naturalizados em uma relação de poder punitivo, repercute na investigação das "práticas pedagógicas dentro e fora do ensino de filosofia" como terceira categoria. Silva (2019) reflete que a própria organização dos currículos das licenciaturas e a experiência na maioria das disciplinas de Estágio Supervisionado não concebem "práticas de um ensino mais articulado com as várias dimensões da vida, ficando reduzido a conteúdos selecionados pelo livro didático, isto é, herança de um currículo de formação de professores centrado em um modelo de divisão disciplinar" (p. 89). Trata-se de um modelo linear que isola os componentes curriculares e os separa das dimensões cotidianas e plurais de estudantes (MARASCHIN, 2004). O que está posto é a descontinuidade entre a prática pedagógica e o currículo escolar, que, em uma abordagem multirreferencial, possibilitaria inventividade na recriação tanto das práticas quanto dos conteúdos curriculares.

Souza (2020) pondera que considerar as complexidades das práticas pedagógicas pode abrir as concepções de ensino para professoras/es, tendo em conta as percepções e processos de estudantes. A autora expõe um recorte de diálogo com estudante no qual este questiona: "Professora, depois que Truman descobriu a verdade, que era um fantoche de um programa de TV, ele escolheu atravessar a porta entre a mentira e a verdade. Certo. Mas será que, depois que ele foi para o mundo real, a mentira deixou de existir?" (SOUZA, 2020, p. 59). Em uma decomposição das formações e práticas reducionistas, as falas, as percepções e os sentidos revelados por estudantes, como também por professoras/es, tornam-se fontes de conhecimento tão significativas quanto o livro didático e podem ser capazes de desnaturalizar sistemas hierárquicos de punição. 


\subsubsection{Ensino de filosofia e o filosofar com a vida cotidiana}

O movimento das peneiradas em torno do que se mostra de micropolíticas educativas nas dissertações abre, para nosso olhar e nosso ouvir, uma questão fundamental para o ensino de filosofia: como "filosofar com a vida cotidiana de estudantes" se aprendemos a reproduzir ensinamentos universalistas dos conceitos e da própria história da Filosofia? Esta indagação aparece como quarta categoria quando Oliveira (2019) aponta que, nas falas de estudantes, há "problemas éticos, educacionais, ambientais, existenciais, questões de gênero, raça e classe, entre tantos outros (...) foi possível tratar de assuntos que não constavam no livro didático, mas que eram de interesse da comunidade e poderiam ser tratados pela Filosofia" (p. 73). Oliveira, ao dizer "poderiam ser tratados pela Filosofia", demonstra um processo formativo reducionista transmitido pela maioria das graduações em Filosofia, em que uma/um professora/or se atém apenas ao livro didático e não consegue ter segurança e criatividade para tomar as questões expressas de estudantes e de suas comunidades (MACHADO, 1990; SOUZA; VIOTTO FILHO, 2018) como questões filosóficas.

Tal desacomodação apresenta-se na dissertação de Silva (2019) quando denota que é preciso incentivar professoras/es, tanto da área de Filosofia quanto das outras áreas, a perceberem que "categorias analisadas perpassam ideias-chaves que estão presentes nos discursos dos professores (...), vias que possam ser eixos de conexões, dialogais entre os conhecimentos" (p. 111-112). A conexão entre formação e práticas pedagógicas, nas quais ideias contextualizadas favorecem o reconhecimento de dicotomias e reduções, pode revelar-se como transformadora e desnaturalizadora do ensino de filosofia.

A dissertação de Souza (2020) também indica essa desacomodação ao apontar que "os temas sobre amor, felicidade, família, política, ritos de passagem (casamento, amadurecimento, nascimento, morte, etc.) são temas universais, mas serão confrontados com a vida efetiva, concreta" (p. 66). Deste lugar, pode-se perguntar pela universalidade, pelas tessituras do real e pelo modo de ensino que se estabelece nas aulas de Filosofia (CERLETTI, 2009). O que se indaga: é possível, sem transformar as compreensões sobre filosofia, mudar os modos de ensino e os currículos produzidos dentro dessas concepções, especialmente em solo brasileiro? 


\subsubsection{Multimodos de tratar as aulas de filosofia}

A percepção de que há diversos caminhos ou "multimodos para se tratar o ensino de filosofia" mostra-se como uma micropolítica que recorta as três dissertações, despontando como quinta categoria. Para Souza (2020), coloca-se a questão do significado da abstração no ensino de filosofia, que teria relação com as camadas distintas de interpretação e com o potencial de imprevisível vivência pedagógica que cria outros modos de conhecer e fabricar conceitos (DELEUZE; GUATTARI, 2010). Por exemplo, a experiência com cinema, mesmo com diversas dificuldades logísticas dentro das escolas, mostra-se como um potencial gerador de outros modos de conhecer e criar o conceito. De fato, "o exercício filosófico, assim como a imagem em movimento, não é estagnado por apreensões dogmáticas, mas estarão sempre passíveis de novas abordagens" (SOUZA, 2020, p. 67). Para a autora, a diversão de assistir a um filme com a turma torna-se uma estratégia profunda no percurso de confecção de sentidos conceituais filosóficos provindos das vivências subjetivas.

Essa compreensão também circula na dissertação de Silva (2019). Mesmo que a autora tenha trabalhado com professoras/es de diversas áreas, a vivência com o grupo dialogal aponta "momentos construtivos para as trocas de experiências (...) e reflexões, que favoreceram a elevação do nível de consciência dos docentes (...) que promovam a religação dos saberes, almejando a complexidade" (p. 111-112). Indica-se o grupo dialogal como espaço de sensibilização em torno do ensino problematizador (COUTINHO, 2011).

A dissertação de Oliveira (2019) acrescenta que o problematizador está repleto do criativo, com o qual os conteúdos filosóficos estudados podem agregar as produções de textos a outras formas de aprendizado, como "poemas, pinturas, quadrinhos sobre a felicidade; animações, instalações, aplicativos que tratavam da dúvida metódica cartesiana; performances, crônicas, romances sobre a consciência; encenação teatral, fotografias, esculturas sobre o diálogo; jogos, montagens, vídeos sobre o argumento" (p. 74). Esses outros modos de sentido estético-racionais põem em desacomodação não apenas o conteúdo, o ensino, a avaliação, o currículo, mas o próprio modo de concepção da filosofia como lugar formativo de problematizações do "normal", de suspensões conceituais diante do cotidiano e de rupturas com as repetições que permeiam o seu próprio ensino. 


\section{Considerações finais: a ATD como peneira fecunda na pesquisa do ensino de filosofia}

Diante de tantas e tamanhas peneiradas, este artigo afirma a contribuição da ATD como um desvelamento epistemológico e metodológico das abordagens qualitativas nas dissertações aqui analisadas. Tais dissertações são produtos de um esforço de qualificação do ensino de filosofia na educação básica, por meio do PROFFILO. Essas produções apontam para um ensino de filosofia que se desafia a adentrar, de modo profundo e sistemático, no chão plural das escolas. Com isso, as teorizações tornam-se pontes entre o campo racional e o empírico, a partir das vivências cotidianas. A forma de proceder da ATD, que articula percepções de elementos comuns em categorias, nascidas de uma leitura singular, intencional e consciente das unidades de significado, indica que esse caminho teórico é possível e que fortalece o ensino de filosofia como área de pesquisa filosófica.

Por meio da ATD, as análises de viés fenomenológico possibilitaram a criação de sentidos no percurso de desmonte dos textos das dissertações analisadas, por meio da unitarização, que aglutinou as unidades de significado, posteriormente articuladas entre si em categorias iniciais e finais. Esse trajeto foi de demonstrar aquilo que apareceu de aproximação entre os sentidos constituídos pelas/os pesquisadoras/es e a forma como vivenciaram as etapas do método fenomenológico enquanto abertura para o interrogar e o compreender o mundo das vivências dos sujeitos da pesquisa em busca da apreensão do objeto investigado. Esse itinerário deu-se mediante diálogo dos sujeitos da pesquisa e das/os pesquisadoras/es, que puderam olhar juntas/os para o sentido do fenômeno. Pela vivência do método fenomenológico, é possível criar outras compreensões da realidade em que se está inserida/o. O ensino de filosofia, através das lentes fenomenológicas das/os pesquisadoras/es junto aos sujeitos investigados, pode ampliar a visão de mundo, de ser humano e de processo educativo, na medida em que atinge a essência do fenômeno pesquisado.

Com o uso da pesquisa-ação, tanto como caminho metodológico, quanto pressuposto teórico para a prática docente, indicam-se outras temáticas que podem ser abordadas nas pesquisas sobre o ensino de filosofia, como questões referentes às subjetividades, pesquisas coletivas e prática docente como lugar de pesquisa, o que pode favorecer transformações no fazer pedagógico de professoras/es de Filosofia na educação básica. Essas temáticas são frutos da exaustiva análise e da intenção de 
interpretar e descrever o que se mostrou nas pesquisas qualitativas no PROF-FILO, por meio da ATD, tomando as escritas de docentes pesquisadoras/es que investigam seus cotidianos como um reinventar a si mesmas/os e seus fazeres com suas/seus estudantes, no saber-fazer filosofia, reconhecendo a importância dessas rotas na formação escolar.

As/Os docentes pesquisadoras/es do ensino de filosofia são convidadas/os, com a aplicação da pesquisa-intervenção, de acordo com as peneiradas provocadas pela ATD, a revisarem percursos de naturalização das situações "acomodadas" nos ambientes escolares e no ensinar-aprender filosofia. Isso pode apontar pesquisas sobre práticas pedagógicas reducionistas e/ou transformadoras/complexas no seu fazer dentro e fora de sala de aula, de modo provocativo. Outro ponto é a tensão entre a universalidade conceitual que recorta os cursos de graduação e licenciatura de Filosofia e os dilemas/indagações provindos da vida cotidiana de estudantes - de que modo abordar e repercutir essa tensão em outras pesquisas? Um terceiro aspecto é a exposição de multimodos de tratar as aulas de Filosofia enquanto práticas pedagógicas que repensam o currículo escolar, os formatos avaliativos vigentes e os jogos das micropolíticas presentes nas vivências escolares e nas concepções filosóficas em chão brasileiro. Uma abordagem multirreferencial, provocada pela pesquisa-intervenção, torna-se possibilidade de atuação consciente, instigadora, problematizadora e criativa na apreensão/recriação de conceitos, de processos de aprendizagens filosóficas e de pesquisas na área do ensino de filosofia.

Afirmamos que esses tipos de pesquisas, dentro da abordagem qualitativa, com a valiosa contribuição da ATD, apresentam uma singular percepção e ampliação das potencialidades das pesquisas realizadas no PROF-FILO. Sendo assim, há que demandar tempo e disponibilidade para acompanhar o cotidiano coletivo das escolas, em redes de significados, de recorrências, de compreensões, de inferências da gênese teórica e social/cultural dos resultados, conceitos e teorias elaboradas dentro/com/por tais pesquisas.

\section{Referências}

ANDRÉ, M.; GATTI, B. A relevância dos métodos de pesquisa qualitativa em Educação no Brasil. In: WILLER, W; PFAFF, N. (org.). Metodologias da pesquisa qualitativa em educação. 3 ed. Petrópolis, RJ: Vozes, 2013. p. 29-38.

ARAÚJO, C. de M. S. Ensinar e aprender filosofia numa perspectiva ética: uma proposta de intervenção numa escola pública. 2019. Dissertação (Mestrado Profissional em Filosofia) - 
Universidade Federal do Piauí, Teresina, 2019. Disponível em:

http://www.humanas.ufpr.br/portal/prof-filo/dissertacoes-defendidas/. Acesso em: 21 set. 2020.

BELLO, A. A. Introdução à fenomenologia. Tradução Ir. Jacinta Turolo Garcia; Miguel Mahfoud. Bauru-SP: Edusc, 2006.

BICUDO, M. A. V. (org.). Pesquisa qualitativa segundo a visão fenomenológica. São Paulo: Cortez, 2011.

BONAMIGO, I. S. et al. Pesquisa-intervenção sobre violências em escolas. Revista Quadrimestral da Associação Brasileira de Psicologia Escolar e Educacional, São Paulo, v. 18, n. 3, p. 519-527, setembro/dezembro, 2014. Disponível em:

www.scielo.br/pdf/pee/v18n3/1413-8557-pee-18-03-0519.pdf. Acesso em: 17 jan. 2020.

BRASIL. Ministério da Educação. Lei Ordinária 11.684 de 02 de junho de 2008. Altera o art. 36 da Lei 9394, de 20 de dezembro de 1996, que estabelece as diretrizes e bases da educação nacional, para incluir a Filosofia e a Sociologia como disciplinas obrigatórias nos currículos do ensino médio. Diário Oficial da União, Brasília, 2008. Disponível em: http://www.planalto.gov.br/ccivil_03/_ato2007-2010/2008/lei/111684.htm. Acesso em: 24 out. 2020.

BRASIL. Ministério da Educação. Gabinete do Ministro. Portaria n. 17 de 28 de dezembro de 2009. Brasília, 2009. Disponível em: https://www.gov.br/capes/pt-br/centrais-deconteudo/portarianormativa-17mp-pdf/view. Acesso em: 24 out. 2020.

CANDAU, V. M. F. Cotidiano escolar e práticas interculturais. Cadernos de Pesquisa, São Paulo, v. 46, n. 161, p. 802-820, setembro, 2016. Disponível em: http://dx.doi.org/10.1590/198053143455. Acesso em: 11 jul. 2020.

CERLETTI, A. O ensino de Filosofia como problema filosófico. Belo Horizonte: Autêntica Editora, 2009.

COUTINHO, L. G. Pesquisa-intervenção na escola: adolescência, educação e inclusão social.

Revista Arquivos Brasileiros de Psicologia, Rio de Janeiro, v. 63, n. 1, p. 1-10, 2011.

Disponível em: pepsic.bvsalud.org/pdf/arbp/v63n1/v63n1a02.pdf. Acesso em: 20 mar. 2020.

DELEUZE, G.; GUATTARI, F. O que é filosofia? 3 ed. São Paulo: Editora 34, 2010.

FRANCO, M. A. S. Pedagogia da Pesquisa-ação. Revista Educação e Pesquisa, São Paulo, v. 31, n. 3, p. 483-502, set./dez. 2005. Disponível em:

https://www.scielo.br/scielo.php?pid=S1517-97022005000300011\&script=sci_abstract\&tlng=pt Acesso em: 24 out. 2020.

FRANCO, M. A. S. Pesquisa-ação e prática docente: articulações possíveis. In: PIMENTA, S. G.; FRANCO, M. A. S. (org.). Pesquisa em Educação: possibilidades investigativas/formativas da pesquisa-ação. 2 ed. São Paulo: Edições Loyola, 2012. p. 103-138.

GAMBOA, S. S. Pesquisa em educação: métodos e epistemologias. 2. ed. Chapecó, SC: Argos, 2012.

GIL, A. C. Métodos e técnicas de pesquisa social. 6. ed. São Paulo: Atlas, 2008.

GODOY, A. S. Introdução à pesquisa qualitativa e suas possibilidades. Revista de Administração de Empresas, São Paulo, v. 35, n. 2, p. 57-63, mar./abr. 1995. 
GONZÁLEZ REY, F. L. A pesquisa e o tema da subjetividade em educação. Revista

Psicologia da Educação, São Paulo, v. 13, n. 13, p. 9-15, 2001. Disponível em:

https://revistas.pucsp.br/index.php/psicoeduca/article/view/32815/22634. Acesso em: 23 out. 2020.

HUSSERL, E. A ideia da fenomenologia. Tradução Artur Morão. Lisboa/Portugal: Edições 70, 2012.

HUSSERL, E. Idéias para uma fenomenologia pura e para uma filosofia fenomenológica: introdução geral à fenomenologia pura. Tradução Márcio Suzuki. São Paulo: Idéias \& Letras, 2006.

MACHADO, A. M. Inventando uma intervenção na Escola Pública. Dissertação (Doutorado em Psicologia: Psicologia Social). Instituto de Psicologia, Universidade de São Paulo, São Paulo, 1990. Disponível em: http://www.teses.usp.br/teses/disponiveis/47/47134/tde-03122013150122/pt-br.php. Acesso em: 10 mar. 2020.

MALLMANN, E. M. Pesquisa-ação educacional: preocupação temática, análise e interpretação crítico-reflexiva. Cad. Pesqui., São Paulo, v. 45, n. 155, p. 76-98, mar. 2015. Disponível em: http://www.scielo.br/scielo.php?script=sci_arttext\&pid=S010015742015000100076\&lng=pt\&nrm=iso. Acesso em: 13 out. 2020.

MARASCHIN, C. Pesquisar e intervir. Revista Psicologia \& Sociedade, Recife, v. 16, n. 1, p. 98-107, 2004. Disponível em: http://www.scielo.br/pdf/psoc/v16n1/v16n1a08. Acesso em: 10 mar. 2020.

MARTINS, J; BICUDO, M. A. V. A pesquisa qualitativa em Psicologia. Fundamentos e recurso básicos. São Paulo: Editora Moraes, 1989.

MARTINS, J.; BOEMER, M. R.; FERRAZ, C. A. A fenomenologia como alternativa metodológica para pesquisa: algumas considerações. Rev. Esc. Enf. USP, São Paulo, v. 24, n. 1, p. 139-147, abr. 1990. Disponível em: https://doi.org/10.1590/0080- 234199002400100139 Acesso em: 10 de nov. 2020.

MCMILLAN, J. H.; SCHUMACHER, S. Investigación educativa: una introducción conceptual. 5. ed. Madrid: Pearson Educación, 2005. Disponível em: http://www.freelibros.me. Acesso em: 23 nov. 2020.

MORAES, R.; GALIAZZI, M. do C. Análise Textual Discursiva. 3. ed. Ijuí: Editora Unijuí, 2016.

MORAES, R. Uma tempestade de luz: a compreensão possibilitada pela análise textual discursiva. Revista Ciência \& Educação, São Paulo, v. 9, n. 2, p. 191-211, jan. 2003. Disponível em: http://www.scielo.br/pdf/ciedu/v9n2/04. Acesso em: 08 fev. 2018.

MONTEIRO, G. M. T. Ensino de Filosofia no ensino médio: contributos da Fenomenologia para a prática docente. 2019. Dissertação (Mestrado Profissional em Filosofia) - Departamento de Filosofia, Universidade Federal de Pernambuco, Recife, 2019. Disponível em:

http://www.humanas.ufpr.br/portal/prof-filo/dissertacoes-defendidas/. Acesso em: 21 set. 2020.

OLIVEIRA, R. S. Educação estética em Marcuse: Avaliação em filosofia para além do textual. 2019. Dissertação (Mestrado Profissional em Filosofia) - Departamento de Filosofia, 
Universidade Federal do Tocantins, Palmas, 2019. Disponível em:

http://www.humanas.ufpr.br/portal/prof-filo/dissertacoes-defendidas/. Acesso em: 21 set. 2020.

PAULON, S. M. A Análise de Implicação como Ferramenta na Pesquisa-intervenção. Revista Psicologia \& Sociedade, Recife v. 17, n. 3, p. 18-25, set-dez, 2005. Disponível em: http://www.scielo.br/pdf/psoc/v17n3/a03v17n3.pdf. Acesso em: 10 nov. 2020.

POCAHY, F. A. Botando corpo, (des) fazendo gênero. Uma ferramenta para a pesquisaintervenção na educação. Revista Reflexão e Ação, Santa Cruz do Sul, v. 24, n. 1, p. 289-308, jan-abri, 2016. Disponível em: http://online.unisc.br/seer/index.php/reflex/index. Acesso em: 10 nov. 2020.

RIBEIRO, R. J. O mestrado profissional na política atual da Capes. Revista Brasileira de PósGraduação, Brasília-DF, v. 2, n. 4, p. 8-15, jul. 2005. Disponível em:

https://doi.org/10.21713/2358-2332.2005.v2.72. Acesso em: 11 dez. 2020.

ROCHA, M. L.; AGUIAR, K. F. de. Pesquisa-Intervenção e a Produção de Novas Análises. Revista Psicologia Ciência e Profissão, Brasília, v. 23, n. 4, p. 64-73, 2003. Disponível em: http://www.scielo.br/pdf/pcp/v23n4/v23n4a10.pdf. Acesso em: 10 nov. 2020.

ROJAS, J. et al. Fenomenologia e rigor na pesquisa educacional: a experiência da UFMS. In: SEMINÁRIO INTERNACIONAL DE PESQUISA E ESTUDOS QUALITATIVOS, 4., 2010, Rio Claro. Anais... Rio Claro: UNESP, 2010. p. 1-10. Disponível em: https://arquivo.sepq.org.br/IV-SIPEQ/Anais/artigos/80.pdf. Acesso em: 2 dez. 2020.

SANTOS, B. de S. Introdução a uma ciência pós-moderna. Rio de Janeiro: Graal, 1989.

SILVA, M. S. L. da. A problematização filosófica como paradigma da construção do pensamento complexo: uma proposta curricular de intervenção. 2019. Dissertação (Mestrado Profissional em Filosofia) - Departamento de Filosofia, Universidade Federal do Piauí, Teresina, 2019. Disponível em: http://www.humanas.ufpr.br/portal/prof-filo/dissertacoesdefendidas/. Acesso em: 22 set. 2020.

SILVA, J. G. da. O ensino de Filosofia: um diálogo com a educação interdimensional na formação de um jovem solidário, autônomo e competente / José Gilberto da Silva. 2019. Dissertação (Mestrado Profissional em Filosofia) - Departamento de Filosofia, Universidade Federal de Pernambuco, Recife, 2019. Disponível em: http://www.humanas.ufpr.br/portal/proffilo/dissertacoes-defendidas/. Acesso em: 15 set. 2020.

SOARES JÚNIOR, A. B. Nietzsche e o ensino de filosofia: uma metodologia para o ensino médio. 2019. Dissertação (Mestrado Profissional em Filosofia) - Departamento de Filosofia, Universidade do Estado do Rio Grande do Norte, Caicó- RN, 2019. Disponível em:

http://www.humanas.ufpr.br/portal/prof-filo/dissertacoes-defendidas/. Acesso em: 21 set. 2020.

SOUZA, F. R. S.; VIOTTO FILHO, I. A. T. Pesquisa-intervenção formativa na escola: dialogando com gestores, professores e estudantes. Revista Colloquium Humanarum, Presidente Prudente, v. 15, n. 1, p. 105-118, jan./mar., 2018. Disponível em: http://journal.unoeste.br/index.php/ch/article/view/2138. Acesso em: 10 nov. 2020.

SOUZA, M. De F. P. R. de M. Indústria cultural x conceito-imagem em Adorno e Cabrera: Uma proposta de intervenção a partir do uso de cinema no Ensino de Filosofia. 2020. Dissertação (Mestrado Profissional em Filosofia) - Departamento de Filosofia, Universidade Federal de Pernambuco, Recife, 2020. Disponível em: http://www.humanas.ufpr.br/portal/proffilo/dissertacoes-defendidas/. Acesso em: 21 set. 
2020.

THIOLLENT, M. Metodologia da pesquisa-ação. 18. ed. São Paulo: Cortez, 2011.

TOURINHO, C. D. C. Afirmação da existência e elucidação do sentido do mundo: a circularidade na dupla preocupação da fenomenologia de Husserl. Revista de Filosofia Moderna e Contemporânea. [S.1.] v. 3, n. 2, p. 30-31, mar. 2016. Disponível em: https://doi.org/10.26512/rfmc.v3i2.12509. Acesso em: 15 oct. 2020.

VELASCO, P. D. N. O que é isto - o PROF-FILO? O que nos faz pensar, [S.1.], v. 28, n. 44, p. 76-107, jul. 2019. Disponível em: http://www.oquenosfazpensar.fil.pucrio.br/index.php/oqnfp/article/view/659. Acesso em: 25 oct. 2020.

Recebido em: 30 de outubro de 2020.

Aceito em: 21 de novembro de 2020. 